\title{
Fish consumption and the risk of gastric cancer: systematic review and meta-analysis
}

Shengjun $\mathrm{Wu}^{1 \dagger}$, Jie Liang ${ }^{2+}$, Lei Zhang ${ }^{3+}$, Xia Zhu', Xufeng Liu', Danmin Miao ${ }^{1 *}$

\begin{abstract}
Background: Gastric cancer is the fourth most frequently occurring malignancy after lung, breast, and colorectal cancer, and the second most common cause of death from cancer worldwide. Epidemiologic studies have examined the possible association between fish consumption and gastric cancer, but the results were inconclusive. We conducted a systematic review and meta-analysis to examine the association between fish intake and the risk of gastric cancer.

Methods: PubMed was searched for studies published in English-language journals from 1991 through 2009. We identified 17 epidemiologic studies (15 case-control and 2 cohort studies) that included relative risks (RRs) or odds ratios (ORs) estimates with 95\% confidence intervals ( $\mathrm{Cls}$ ) of the relationship between gastric cancer and fish consumption. Data were extracted using standardized data forms. Summary RRs or ORs for the highest versus non/lowest fish consumption levels were calculated using random-effects model. Heterogeneity among studies was examined using $Q$ and $I^{2}$ statistics.

Results: In this study, 5,323 cases of gastric cancer and over 130,000 non-cases were included. The combined results from all studies indicated that the association between high fish consumption and reduced gastric cancer risk was not statistically insignificant $(\mathrm{RR}=0.87,95 \% \mathrm{Cl}=0.71-1.07)$.
\end{abstract}

Conclusions: Current evidence indicated that the association between fish consumption and risk of gastric cancer remains unclear.

\section{Background}

Gastric cancer is the fourth most frequently occurring malignancy, after lung, breast and colorectal cancer, and the second most common cause of death from cancer worldwide [1,2]. It has been estimated that 1 million patients are newly diagnosed with gastric cancer worldwide each year, with 700,000 patients dying from this disease annually [1].

Diet has been found to be important factor in the development of gastric cancer [3-6]. A report published in 2007 by the World Cancer Research Fund and the American Institute for Cancer Research on the relationship between diet and cancer suggested that the consumption of certain types of food may be directly associated with the development of this disease [7].

\footnotetext{
* Correspondence: psyfmmu@126.com

+ Contributed equally

'Department of Psychology, School of Aerospace Medicine, Fourth Military

Medical University, Xi'an, Shaanxi, PR China

Full list of author information is available at the end of the article
}

Fish is part of the usual diet of most people worldwide and is an ideal source of n-3 fatty acids, which are important components of cell membranes [8]. These long-chain fatty acids have been reported to suppress mutations, inhibit cell growth, and enhance cell apoptosis, thus reducing the risk of cancer [9-11]. To date, however, there have been no intervention studies examining the association between fish consumption and the risk of gastric cancer. Although several epidemiological studies have focused on this association, their conclusions have been inconsistent [12-28]. We therefore preformed a systematic review and meta-analysis to assess the association between fish consumption and gastric cancer risk.

\section{Methods}

Data Sources and Searches

We comprehensively searched through PubMed for all medical literature published in English-language journals up to January 2009. In searching outcomes, we used the search terms stomach neoplasms[MeSH] OR gastric
C Biomed Central

(C) 2011 Wu et al; licensee BioMed Central Ltd. This is an Open Access article distributed under the terms of the Creative Commons Attribution License (http://creativecommons.org/licenses/by/2.0), which permits unrestricted use, distribution, and reproduction in any medium, provided the original work is properly cited. 
neoplasms[tiab] OR stomach cancer[tiab] OR gastric cancer[tiab] OR stomach carcinoma[tiab] OR gastric carcinoma[tiab] OR stomach tumor[tiab] OR gastric tumor [tiab]. In searching exposure, we used the terms food [MeSH] OR diet[MeSH] OR diets[tiab] OR dietetic[tiab] OR dietary[tiab] OR eating[tiab] OR intake[tiab] OR nutrient[tiab] OR nutrition[tiab] OR fish[tiab] OR seafood [tiab]. For the search on study design, we used the terms case-control studies [MeSH] OR retrospective studies [MeSH] OR cohort studies [MeSH] OR prospective studies $[\mathrm{MeSH}]$. In addition, we reviewed the reference lists from all relevant articles to identify additional studies.

\section{Study Selection}

Studies that met the following criteria were included in the meta-analysis: 1) the study was either a case-control or cohort study; 2) the exposure of interest was fresh fish consumption; 3) the study reported the number of gastric cancer cases and controls or non-cases; and 4) the study reported relative risks (RRs) or odds ratios (ORs) with their corresponding 95\% confidence intervals (CIs) for the highest versus non/lowest level of fish intake. Two authors (Zhu and Liu) screened all references; if they differed as to whether to include a study, that study was discussed by all authors, with decision to include based on voting.

\section{Data Extraction and Quality Assessment}

If data were duplicated in more than 1 study, the most recent study was included in the analysis. We identified 18 potentially relevant articles concerning fish consumption and gastric cancer risk [12-29]. Three authors (Wu, Liang and Zhu) performed data extraction and quality assessment; again any discrepancies were settled by a discussion and vote by all authors.

One study was excluded because fish consumption was compared between meat eaters and non-meat eaters [29]. Seventeen studies were included in the meta-analysis of fish intake and gastric cancer: 15 case-control studies and 2 cohort studies. We used a standardized protocol and reporting form to abstract the following data from each publication: reference (first author, year of publication), study design, country in which the study was performed, numbers of cases and non-cases, lowest and highest levels of fish consumption, the RR or OR with $95 \%$ CI for gastric cancer associated with fish intake, covariate adjustments, the methods used for dietary assessment.

\section{Data Synthesis and Analysis}

Study-specific ORs/RRs with corresponding 95\% CIs for highest versus non/lowest fish consumption levels were extracted. If the study provided both different and general estimates, we included only the general results. For example, if the study included ORs/RRs and 95\% CIs of males and females and both genders combined, we included only the combined data in our meta-analysis. For case-control studies, the proportions (expressed as percentages) of control subjects in the highest and non/lowest consumption categories were included. For cohort studies, the percentages of subjects in categories of the highest and non/lowest consumption levels were calculated as the number of subjects in each of these 2 categories relative to the total number of study subjects.

$\mathrm{Q}$ and Higgins $\mathrm{I}^{2}$ statistics were used to examine heterogeneity not only among studies but also between the subgroups included in this meta-analysis [30,31]. For the $\mathrm{Q}$ statistics, $\mathrm{P}<0.10$ indicated statistically significant heterogeneity [30]. We defined statistical significance as $\mathrm{P}<$ 0.10 rather than the conventional level of 0.05 because of the low power of this test [32]. $\mathrm{I}^{2}$ values lie between $0 \%$ (no observed heterogeneity) and 100\% (maximal heterogeneity); thus, an $\mathrm{I}^{2}$ value greater than $50 \%$ may be considered to represent substantial heterogeneity [31]. Risk estimates were calculated using a random-effects model, incorporating both within- and between-study variability [30]. Summary estimates were calculated for each type of study design (case-control and cohort) as well as for their combination.

To assess the potential for publication bias, we used funnel plots and Egger's regression [33,34]. All statistical analyses were performed with Stata (Version 10.0; StataCorp, College Station, TX).

\section{Results}

\section{Literature Search}

The detailed steps of our literature search are shown in Figure 1. In brief, our search found that, of 659 potential articles, 73 concerned fish consumption and the risk of gastric cancer. Of these 73, 55 were excluded because they were review articles, ecological or laboratory studies, or did not provide sufficient information. One

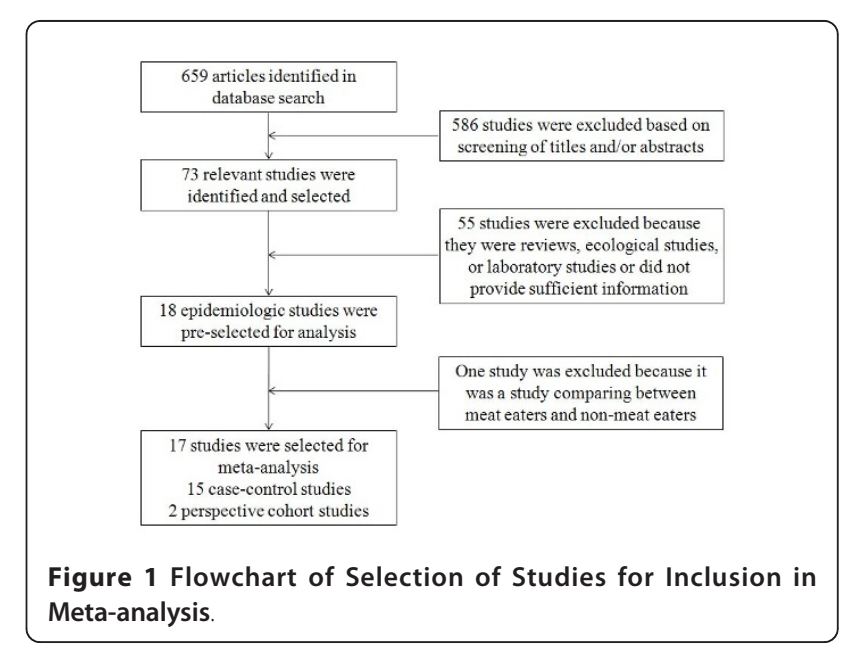


study was excluded because it compared meat eaters and non-meat eaters [29]. We also searched all of references in the 73 relevant articles for additional studies. Finally, 17 studies were included in the meta-analysis.

\section{Study Characteristics}

The 17 articles that met the inclusion criteria for our meta-analysis were published between 1991 and 2009 and involved a total of 5,323 cases and 130,903 noncases. Of these 17 studies, 8 were population-based case-control studies $[12,13,18-20,22,25,26]$, 7 were hospital-based case-control studies [14-17,21,23,24], and 2 were cohort studies $[27,28]$.

\section{Meta-Analysis}

The lowest and highest levels of fish consumption and the RR or OR for each of the 17 included studies, along with their summary OR, are shown in Table 1 and Figure 2.

We observed significant heterogeneity in the results of these 17 studies $\left(\mathrm{Q}=59.92, \mathrm{P}<0.001, \mathrm{I}^{2}=73.3 \%\right)$. The summary OR for all of the studies showed that high fish consumption was not associated with a reduction in risk of gastric cancer (summary $\mathrm{RR}=0.87,95 \% \mathrm{CI}=0.71-1.07$ ).

Significant heterogeneity was found among the 15 case-control studies $\left(\mathrm{Q}=58.39, \mathrm{P}<0.001, \mathrm{I}^{2}=76.0 \%\right)$ but not between the 2 cohort studies $(\mathrm{Q}=0.07, \mathrm{P}=$ $\left.0.79, \mathrm{I}^{2}=0.0 \%\right)$. Similar to the results from all studies combined, there was no significant association between fish intake and gastric cancer risk either in the case-control (summary OR $=0.85,95 \% \mathrm{CI}=0.68-1.06$ ) or cohort (summary OR $=1.11,95 \% \mathrm{CI}=0.77-1.62)$ studies (Table 2).

When we stratified the various studies by design (case-control versus cohort), we found no significant heterogeneity between the 2 types of study design $(\mathrm{Q}=$ $1.46, \mathrm{P}=0.23, \mathrm{I}^{2}=31.4 \%$ ), or between population-based and hospital-based case-control studies $(\mathrm{Q}=0.07, \mathrm{P}=$ $\left.0.80, \mathrm{I}^{2}=0.0 \%\right)$. However, significant heterogeneity was found among both the population-based $(\mathrm{Q}=39.16, \mathrm{P}<$ $\left.0.001, \mathrm{I}^{2}=82.1 \%\right)$ and hospital-based $(\mathrm{Q}=13.73, \mathrm{P}=$ $0.033, \mathrm{I}^{2}=56.3 \%$ ) case-control studies.

When we stratified the studies geographically (Western versus Asian countries), we also found no significant heterogeneity $\left(\mathrm{Q}=0.35, \mathrm{P}=0.55, \mathrm{I}^{2}=0.0 \%\right)$. However, significant heterogeneity was found among studies performed in Western $\left(\mathrm{Q}=40.14, \mathrm{P}<0.001, \mathrm{I}^{2}=80.1 \%\right)$ and Asian $\left(\mathrm{Q}=19.59, \mathrm{P}=0.007, \mathrm{I}^{2}=64.3 \%\right)$ countries. We found no association between fish intake and gastric cancer risk in either Western (summary OR $=0.92$, 95\% $\mathrm{CI}=0.71-1.19$ ) or Asian (summary OR $=0.80,95 \% \mathrm{CI}=$ $0.54-1.16$ ) countries. When the studies were stratified by method of dietary assessment (face-to-face interview with a questionnaire versus mailed questionnaire), there was significant heterogeneity between the two methods $(\mathrm{Q}=$ $\left.7.95, \mathrm{P}=0.01, \mathrm{I}^{2}=87.4 \%\right)$. Significant heterogeneity was also found among studies using interview assessments $\left(\mathrm{Q}=46.26, \mathrm{P}=0.00, \mathrm{I}^{2}=69.7 \%\right)$ but not among those using mailed questionnaires $\left(\mathrm{Q}=0.29, \mathrm{P}=0.59, \mathrm{I}^{2}=\right.$ $0.0 \%)$. Results of the studies using interviews showed no significant association between fish intake and gastric cancer (summary OR $=0.86,95 \% \mathrm{CI}=0.66-1.02$ ). However, fish consumption was a risk factor for gastric cancer in studies using mailed questionnaires (summary OR = $1.26,95 \% \mathrm{CI}=1.03-1.55)$ (Table 2$)$.

\section{Publication Bias Analysis}

Figure 3 shows a symmetric Begg's funnel plot, indicating that there was no publication bias $(\mathrm{P}=0.51)$. Further, there was no evidence of bias using Egger's test (intercept $=-0.08, \mathrm{P}=0.59$ ).

In addition to the studies used in this meta-analysis, other studies provided potentially important information about fish consumption and gastric cancer in formats other than RR or OR with 95\% CI [35-37]. Those results are shown in Table 3.

\section{Discussion}

The important role played by diet in preventing cancer has received much attention in recent years [38-44]. Our meta-analysis evaluated the strength of current evidence for the effect of fish consumption on the lowering of gastric cancer risk, using studies published in recent years. Most of these studies were primarily designed to investigate the effect of fish consumption on gastric cancer risk. Our meta-analysis was strengthened by the detailed information provided in our study design, including the selection criteria for cases and controls and the methods of data collection.

Overall, the summary OR for all of the studies showed no significant association between fish consumption and the risk of gastric cancer, and no such association was found when the case-control or cohort studies were evaluated individually. There was a statistically significant heterogeneity among the 17 studies on fish consumption and gastric cancer risk. In analyzing risk estimates and $95 \% \mathrm{CI}$, we only used a random-effects model that considered both intra- and inter-study variation. This random-effects model is more conservative, and hence more appropriate, than a fixed-effects model. Thus, our results were derived from the random-effects model, regardless of their condition of homogeneity. Indeed, we found that, across homogeneous studies, the fixed-effects and random-effects models provided similar results.

Using the funnel plots and Egger's method, we observed no publication bias of the effects of fish consumption on risk of gastric cancer. 
Table 1 Characteristics of Studies Included in the Meta-analysis

\begin{tabular}{|c|c|c|c|c|c|c|c|}
\hline Reference & Design & Country & $\begin{array}{l}\text { No. of } \\
\text { Cases/No. of } \\
\text { Non-cases }\end{array}$ & $\begin{array}{l}\text { OR or RR } \\
(95 \% \mathrm{Cl})\end{array}$ & $\begin{array}{l}\text { Fish Consumption } \\
\text { Levels }\end{array}$ & Covariate Adjustment & $\begin{array}{l}\text { Methods Used for Assessing } \\
\text { Dietary Dntake }\end{array}$ \\
\hline Buiatti 1991 & PCC & Italy & $510 / 1159$ & $1.00(0.80-1.30)$ & T3 vs. T1 & $\begin{array}{l}\text { Age, sex, area, place of residence, migration, socioeconomic status, } \\
\text { familiar GC history, Quetelet index, total caloric intake }\end{array}$ & $\begin{array}{l}\text { Interview with a structured } \\
\text { questionnaire }\end{array}$ \\
\hline Chen 2002 & PCC & China & $124 / 449$ & $0.58(0.25-1.40)$ & Q4 vs. Q1 & $\begin{array}{l}\text { Age, sex, energy intake, respondent type, BMl, alcohol use, tobacco use, } \\
\text { eduction, family history, vitamin supplement use }\end{array}$ & $\begin{array}{l}\text { Interview with a modified version } \\
\text { of the short Health Habits and } \\
\text { History Questionnaire }\end{array}$ \\
\hline $\begin{array}{l}\text { Cornée } \\
1995\end{array}$ & $\mathrm{HCC}$ & France & $92 / 128$ & $0.97(0.48-1.96)$ & Q3 vs. Q1 & Age, sex, occupation and total energy intake & $\begin{array}{l}\text { Interview with a dietary history } \\
\text { questionnaire }\end{array}$ \\
\hline $\begin{array}{l}\text { De Stefani } \\
2004\end{array}$ & $\mathrm{HCC}$ & Uruguay & $240 / 960$ & $0.73(0.51-1.03)$ & T3 vs. T1 & $\begin{array}{l}\text { Age, sex, residence, urban/rural status, education, boby mass index, toal } \\
\text { energy intake }\end{array}$ & $\begin{array}{l}\text { Interview with a food frequency } \\
\text { questionnaire (FFQ) }\end{array}$ \\
\hline $\begin{array}{l}\text { Fernandez } \\
1999\end{array}$ & $\mathrm{HCC}$ & Italy & 745/7990 & $0.80(0.70-0.90)$ & $\begin{array}{l}\text { Increment } 1 \text { serving/ } \\
\text { wk vs. } 1 \text { Serving/wk }\end{array}$ & $\begin{array}{l}\text { Age, sex, area of residence, education, smoking, alcohol consumption, } \\
\text { body mass index }\end{array}$ & $\begin{array}{l}\text { Interview with a structured } \\
\text { questionnaire }\end{array}$ \\
\hline $\begin{array}{l}\text { Hamada } \\
2002\end{array}$ & $\mathrm{HCC}$ & Brazil & $96 / 192$ & $0.30(0.10-2.20)$ & Daily vs. $<1 \mathrm{~d} /$ week & Beef comsuption, country of birth & Interview with a questionnaire \\
\hline $\begin{array}{l}\text { Hoshiyama } \\
1992\end{array}$ & PCC & Japan & $216 / 483$ & $0.90(0.50-1.40)$ & $\begin{array}{l}\geq 15 / \text { week vs. } \leq 4 / \\
\text { week }\end{array}$ & & $\begin{array}{l}\text { Interview with a lifestyle } \\
\text { questionnaire }\end{array}$ \\
\hline Hu 2008 & PCC & Canada & $1182 / 5039$ & $1.3(1.00-1.60)$ & $\begin{array}{l}\text { Q3vs. Q1 ( } \geq 5 \text { oz/ } \\
\text { week vs. } \leq 2 \text { oz/ } \\
\text { week) }\end{array}$ & $\begin{array}{l}\text { Age, province, education, body mass index, sex, alcohol use, pack-year } \\
\text { smoking, total of vegetable and fruit intake }\end{array}$ & $\begin{array}{l}\text { Mail with a short version of the } \\
\text { Block food frequency questionnaire } \\
\text { (FFQ) }\end{array}$ \\
\hline $\begin{array}{l}\text { Muñoz } \\
2001\end{array}$ & PCC & France & $302 / 485$ & $0.36(0.22-0.60)$ & Q4 vs. Q1 & age, sex, tobacco, alcohol, total calories and SES & $\begin{array}{l}\text { Interview with a semi-quantitative } \\
\text { food frequency questionnaire (FFQ) }\end{array}$ \\
\hline $\begin{array}{l}\text { Phukan } \\
2006\end{array}$ & $\mathrm{HCC}$ & India & $329 / 665$ & $0.18(0.02-5.30)$ & $\geq 2 /$ week vs. never & Level of education, tobacco use, alcohol drinking, & $\begin{array}{l}\text { Interview with a structured } \\
\text { pretested questionnaire }\end{array}$ \\
\hline $\begin{array}{l}\text { Pourfarzi } \\
2009\end{array}$ & PCC & Iran & $210 / 389$ & $0.37(0.19-0.70)$ & $\begin{array}{l}\geq 1 / \text { week vs. never or } \\
\text { infrequently }\end{array}$ & $\begin{array}{l}\text { Gender, age group, education, family history of GC, citrus fruit, garlic, } \\
\text { onion, red meat, fish, diary products, strength and warmth of tea, } \\
\text { preference for salt intake and H. pylori }\end{array}$ & $\begin{array}{l}\text { Interviewed with a structured } \\
\text { questionnaire }\end{array}$ \\
\hline Rao 2002 & $\mathrm{HCC}$ & India & $119 / 1591$ & $1.4(0.95-2.00)$ & $\begin{array}{l}\text { At least once a week } \\
\text { vs. never or once in } \\
2 \text { weeks }\end{array}$ & Habit, age group and sex & Interview with a questionnaire \\
\hline Ito 2003 & $\mathrm{HCC}$ & Japan & $508 / 36490$ & $0.60(0.40-0.90)$ & $\begin{array}{l}\geq 5 \text { times/week vs. } \\
<1 \text { time/week }\end{array}$ & $\begin{array}{l}\text { Age, year, season at first hospital visit, smoking habit and family history } \\
\text { of gastric cancer }\end{array}$ & $\begin{array}{l}\text { Interview with a self-administered } \\
\text { questionnaire }\end{array}$ \\
\hline $\begin{array}{l}\text { Takezaki } \\
2001\end{array}$ & PCC & China & $187 / 333$ & $1.35(0.64-2.85)$ & $\begin{array}{l}\geq 3 \text { times/week vs. } \\
<1 \text { time/month }\end{array}$ & Age, sex, smoking and drinking & $\begin{array}{l}\text { Interview with a structured } \\
\text { questionnaire }\end{array}$ \\
\hline Ward 1999 & PCC & Mexico & $220 / 752$ & $2.20(1.20-3.80)$ & $\begin{array}{l}\geq 2.6 \text { times/week vs. } \\
<1 \text { time/week }\end{array}$ & $\begin{array}{l}\text { Age, gender, total calories, chilli pepper consumption, added salt, } \\
\text { history of peptic ulcer, cigarette smoking and socioeconomic status }\end{array}$ & $\begin{array}{l}\text { Interview with a semiquantitative } \\
\text { food frequency questionnaire }\end{array}$ \\
\hline $\begin{array}{l}\text { Larsson } \\
2006\end{array}$ & cohort & Sweden & $136 / 61433$ & $1.14(0.75-1.72)$ & Highest vs. lowest & $\begin{array}{l}\text { Age, education, body mass index, intake of total energy, alcohol, fruits } \\
\text { and vegetables }\end{array}$ & $\begin{array}{l}\text { Mail with a food-frequency } \\
\text { questionnaire (FFQ) }\end{array}$ \\
\hline $\begin{array}{l}\text { Ngoan } \\
2002\end{array}$ & cohort & Japan & $107 / 12365$ & $0.90(0.30-2.10)$ & $\begin{array}{l}\geq 1 \text { time/day vs. } \leq 2-4 \\
\text { time/month }\end{array}$ & Sex, age, smoking and other dietary factors & $\begin{array}{l}\text { Interview with a self-administered } \\
\text { questionnaire }\end{array}$ \\
\hline
\end{tabular}




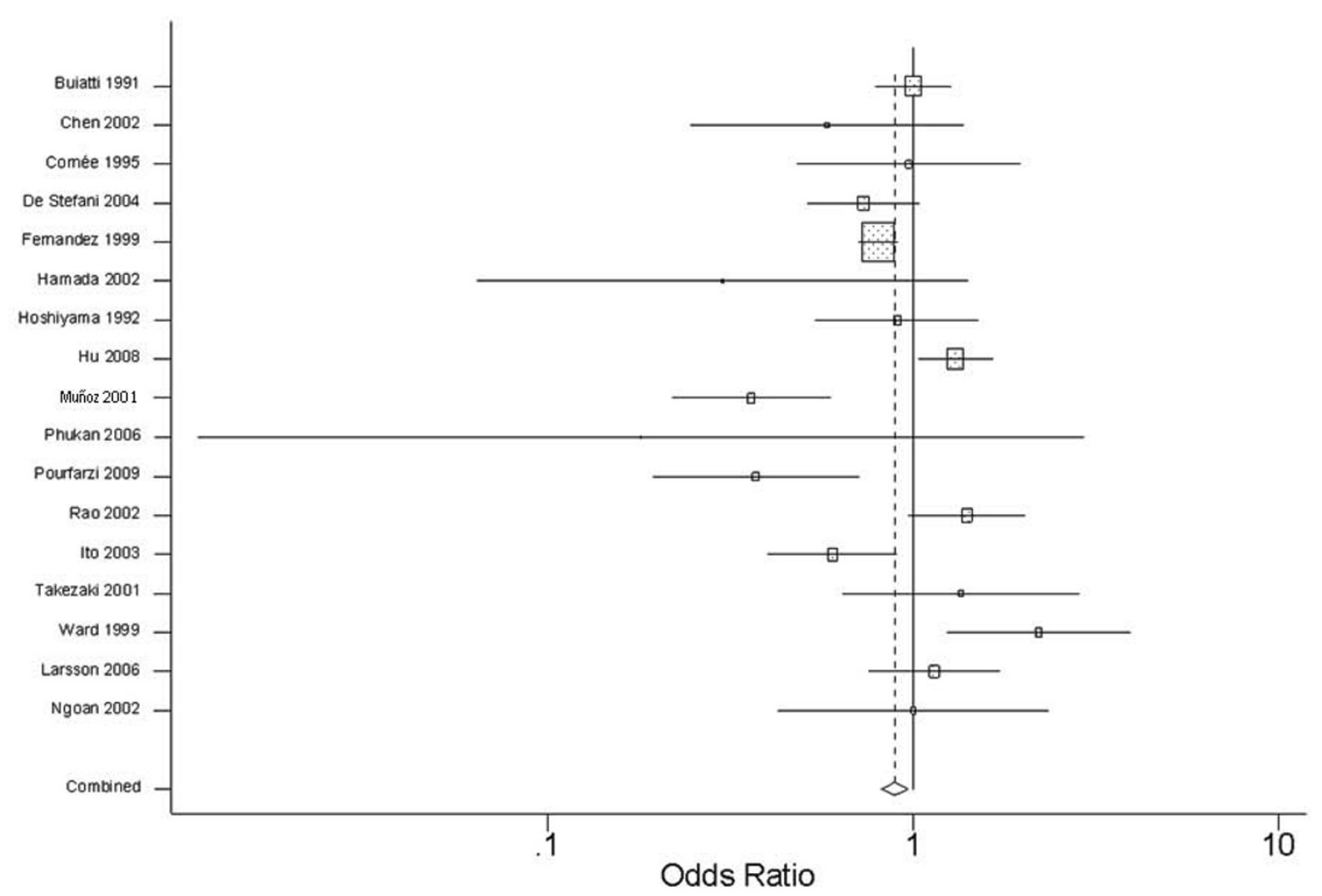

Figure 2 Meta-analysis of All Studies of Gastric Cancer Risk.

One of the 17 studies provided data on consumption of fresh fish and other types of processed fish, but we selected only data on fresh fish consumption [22]. Although there is no conclusive evidence on the association between processed fish intake and risk of gastric cancer, many epidemiological studies and reviews have found that consumption of highly salted food was strongly associated with the risk of gastric cancer [45-51]. This may be due to the presence in highly salted foods, such as salted or smoked fish or processed foods, of chemical carcinogens such as nitrites and their related compounds, or of heterocyclic amines, which

Table 2 Meta-analysis of Fish Consumption and Gastric Cancer Risk

\begin{tabular}{|c|c|c|c|}
\hline Category of Studies & No. of Studies & Summary OR or RR $(95 \% \mathrm{Cl})$ & $1^{2}$ \\
\hline All studies & 17 & $0.87(0.71-1.07)$ & $73.3 \%$ \\
\hline Case-control studies & 15 & $0.85(0.68-1.06)$ & $76.0 \%$ \\
\hline Population-based case-control studies & 7 & $0.87(0.60-1.27)$ & $82.1 \%$ \\
\hline Hospital-based case-control studies & 8 & $0.82(0.63-1.05)$ & $56.3 \%$ \\
\hline Population-based versus hospital-based case-control studies & & & $0.0 \%$ \\
\hline Cohort studies & 2 & $1.11(0.77-1.62)$ & $0.0 \%$ \\
\hline Case-control versus cohort studies & & & $31.4 \%$ \\
\hline Western studies & 9 & $0.92(0.71-1.19)$ & $80.1 \%$ \\
\hline Eastern studies & 8 & $0.80(0.54-1.16)$ & $64.3 \%$ \\
\hline Western versus Eastern studies Mail assessment Interview versus mail assessment & & & $0.0 \%$ \\
\hline Interview assessment & 15 & $0.82(0.66-1.02)$ & $69.7 \%$ \\
\hline Mail assessment & 2 & $1.26(1.03-1.55)$ & $0.0 \%$ \\
\hline Interview versus mail assessment & & & $73.3 \%$ \\
\hline
\end{tabular}

Abbreviations: OR: Odd Risk, RR: Relative Risk; Cl: Confidence Interval. 


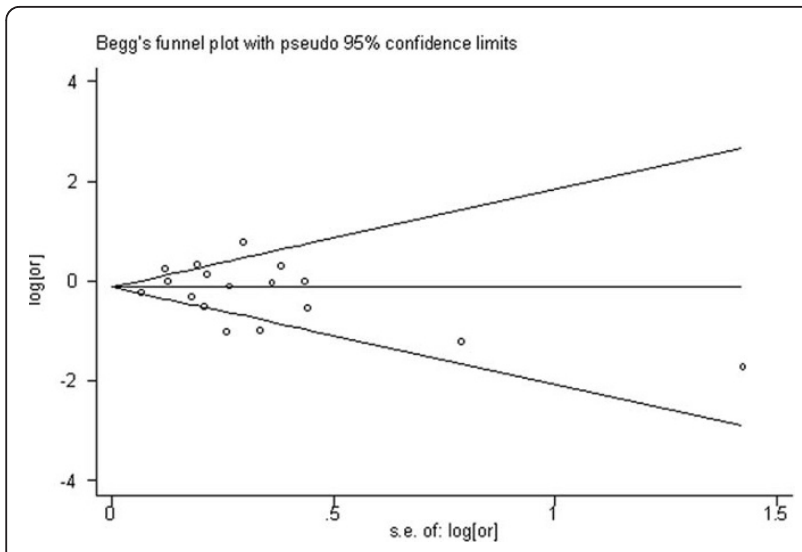

Figure 3 Begg's Funnel Plot of Fish Consumption and Risk of Gastric Cancer.

have been detected in fish or meat cooked at high temperatures, such as grilling [52-58]. In addition to salt and nitrites, 2-chloro-4-methylthiobutanoic acid, a mutagen present in salted fish, may be associated with gastric carcinogenesis [59].

One study reported the OR and 95\% CI of intestinal and other types of gastric cancer; we selected only the data for intestinal gastric cancer [12]. Gastric cancer can be divided into two histological classifications, intestinal and diffuse, which differ in histology, epidemiology, genetic profile, and clinic outcome [60]. The relative frequencies of intestinal and diffuse type cancer have been found to range from $54-72 \%$ and from $10-31 \%$, respectively [61]. More important, many studies have found that the intestinal-type is linked more closely to dietary and environmental risk factors [62-64].

From one study [28], we selected the RR with 95\% CI after excluding patients followed-up less than three years because the preclinical symptoms of stomach cancer might have caused a change in diet and thereby biased the results $[65,66]$. In another study [21], which provided both univariate and multivariate OR with $95 \%$ CI, we selected the data derived from multivariate analysis because univariate OR and 95\% CI were obtained by conditional logistic regression analysis, whereas multivariate OR and $95 \%$ CI were obtained after controlling for many additional factors, including level of education and tobacco use.

Animal model studies have shown that fatty acids can affect the risk of developing cancer [67,68]. Fish and fish oil are rich sources of $\mathrm{n}-3$ fatty acids and may have antiinflammatory potential inhibiting the growth of lung, breast, and colon cancer [69-73]. There may be reasons for the discrepancies observed between our results and the findings of other studies. For example, consumption of freshwater but not marine fish was found to be related to an increased risk of breast cancer [74]. Freshwater fish contain lower levels of omega-3 but higher levels of omega- 6 fatty acids than marine fish, and omega- 6 fatty acids were found to have no significant association with breast or colorectal cancer [75-77]. Most of the studies included in our meta-analysis, however, did not specify what type of fish was consumed.

Second, different methods were used for dietary assessment. Of the 17 studies we included, 4 used the food frequency questionnaire (FFQ) to assess dietary intake $[15,19,20,27]$. This questionnaire has an important role in chronic disease epidemiology and has become the dominant method for assessing food consumption in epidemiological studies [78]. A multi-cultural epidemiologic study has indicated that this questionnaire has reasonable reliability and validity [79]. Two other studies used other dietary questionnaires that have been found to have good reliability and validity $[16,26]$. The other included studies, however, did not provide enough information about the questionnaires they used [12-14,17,18,21-25,28]. In addition, 2 studies used mailed questionnaires to assess dietary patterns, while the other 15 used interview assessments. The results of the 2 studies using mailed questionnaires indicated that fish consumption increased gastric cancer risk, although underlying factors, such as response rate to mailed questionnaires, may have affected these results.

The third reason may be our inclusion of relatively few studies in our meta-analysis. Additional epidemiological studies are needed to obtain definitive results

Table 3 Other Studies Including Information of the Association between Fish Consumption and Risk of Gastric Cancer

\begin{tabular}{|c|c|c|c|c|c|}
\hline Study & Design & Methods & Country & $\begin{array}{l}\text { No. of Cases/No. of } \\
\text { Non-cases }\end{array}$ & Information Provided \\
\hline $\begin{array}{l}\text { Campbell, } \\
2008\end{array}$ & PCC & Factor analysis & Canada & $1169 / 2332$ & $\begin{array}{l}\text { The loading score of fresh fish is larger than } 25 \text { which means fish is a } \\
\text { protective factor for gastric cancer }\end{array}$ \\
\hline $\begin{array}{l}\text { Nomura, } \\
2003\end{array}$ & PCC & $\begin{array}{l}\text { Geometric } \\
\text { mean } \\
\text { comparison }\end{array}$ & USA & $230 / 446$ & $\begin{array}{l}\text { No remarkable differences in the intake of fish between case and control } \\
\text { group }\end{array}$ \\
\hline Kim, 2004 & Cohort & Factor analysis & Japan & $400 / 41712$ & $\begin{array}{l}\text { Fish consumption loads more on traditional dietary pattern than healthy } \\
\text { dietary pattern in male and female respectively. healthy pattern decreased } \\
\text { the risk of gastric cancer among females, while the traditional pattern } \\
\text { increased the risk in both genders }\end{array}$ \\
\hline
\end{tabular}


concerning the association between fish intake and gastric cancer risk.

Although our search identified additional studies with useful information on the association between fish intake and gastric cancer risk, these studies were not included in this analysis. For example, factor analysis showed that the loading score of fresh fish was $>25$, indicating that fish intake was a protective factor against gastric cancer [35]. However, this type of data could not be combined with the other data in our meta-analysis. The exclusion of these useful studies may have influenced our results. We found that the summary RR was 0.87 (95\% CI $=0.71-1.07$ ), suggesting that fish consumption has a marginal preventive effect on the risk of gastric cancer. Inclusion of those other studies may have altered our results.

Similar to all meta-analyses, our meta-analysis has limitations resulting from the availability, quality, and heterogeneity of the published data, and these limitations should be considered when interpreting our results.

First, the methods and units of measuring fish intake varied across studies. For example, since the fish consumption categories were not very clear in some studies, we reported only the lowest and highest categories. This may have been an important source of heterogeneity among these studies.

The second limitation is that we only searched the PubMed database. Searching of other databases, such as EMBASE, CANCERLIT and BIOSIS PREVIEWS, may have identified related studies that were not included in our meta-analysis. Because of this limitation, our results should be interpreted cautiously. Future studies including all available databases should test the validity of our conclusions.

The third limitation is that we included only studies that were published in English, thereby potentially excluding several useful studies.

Our fourth limitation is that our searching strategy used the terms case-control studies [MeSH] OR retrospective studies $[\mathrm{MeSH}]$ OR cohort studies $[\mathrm{MeSH}] \mathrm{OR}$ prospective studies [MeSH]. This may have led to the exclusion of useful studies not indexed by any of these terms.

Lastly, our study is limited because of the small sample size of 17 studies. The further sensitivity analysis restriction may therefore have led to loss of statistical significance for pooled relative risks, although the risk estimates changed only slightly. Because of the small sample size, we had limited power to conclusively reject the null hypothesis of no publication bias. Therefore, we set statistical significance for publication bias at $\mathrm{P}<$ 0.10. However, publication bias was not detected, either visually or by the Egger's test.

\section{Conclusions}

In summary, from the present meta-analysis we still cannot draw conclusion that fish consumption has preventive effects on gastric cancer. Additional epidemiological studies on the association between diet and cancer are needed to reach more definitive conclusions. These studies should focus on the incidence of gastric cancer relative to different dietary categories, different levels of fish consumption, or different types of fish in the diet.

\section{Author details}

${ }^{1}$ Department of Psychology, School of Aerospace Medicine, Fourth Military Medical University, Xi'an, Shaanxi, PR China. ${ }^{2}$ State Key Laboratory of Cancer Biology \& Xijing Hospital of Digestive Diseases, Fourth Military Medical University, Xi'an, Shaanxi, PR China. ${ }^{3}$ Department of Epidemiolody, School of Military Preventive Medicine, Fourth Military Medical University, Xi'an, Shaanxi, PR China.

\section{Authors' contributions}

SW, JL, XZ and DM conceived and designed the study. XZ and XL did the literature search and identified eligible studies. SW, JL and XZ coded articles and decided on their inclusion. SW, XL and LZ did statistical analyses and interpreted results. All drafts of the reports, including the final version, were written by SW and $\mathrm{JL}$ and revised by DM All authors read and approved the final paper.

\section{Competing interests}

The authors declare that they have no competing interests.

Received: 20 April 2010 Accepted: 20 January 2011

Published: 20 January 2011

\section{References}

1. Parkin DM, Bray F, Ferlay J, Pisani P: Global cancer statistics, 2002. CA Cancer J Clin 2005, 55:74-108.

2. Brenner $\mathrm{H}$, Rothenbacher $\mathrm{D}$, Arndt $\mathrm{V}$ : Epidemiology of stomach cancer. Methods Mol Biol 2009, 472:467-477.

3. Nomura A: Stomach cancer. In Cancer epidemiology and prevention. Edited by: Schottenfeld D, Fraumeni J. New York, Oxford University Press; 1996:707-724.

4. Riboli E, Norat T: Cancer prevention and diet: opportunities in Europe. Public Health Nutr 2001, 4(2B):475-484.

5. Key TJ, Schatzkin A, Willett WC, Allen NE, Spencer EA, Travis RC: Diet, nutrition and the prevention of cancer. Public Health Nutr 2004, 7(1A):187-200.

6. Gonzalez CA: Nutrition and cancer: the current epidemiological evidence. Br J Nutr 2006, 96(Suppl 1):42-45.

7. Wiseman M: The second World Cancer Research Fund/American Institute for Cancer Research expert report. Food, nutrition, physical activity, and the prevention of cancer: a global perspective. Proc Nutr Soc 2008, 67:253-256.

8. Simopoulos AP: Omega-3 fatty acids in health and disease and in growth and development. Am J Clin Nutr 1991, 54:438-463.

9. Fernandez E, Chatenoud L, La Vecchia C, Negri E, Franceschi S: Fish consumption and cancer risk. Am J Clin Nutr 1999, 70:85-90.

10. Karmali RA: n-3 Fatty acids and cancer. J Intern Med Suppl 1989, 225:197-200.

11. Rose DP, Connolly JM: Omega-3 fatty acids as cancer chemopreventive agents. Pharmacol Ther 1999, 83:217-244.

12. Buiatti E, Palli D, Bianchi S, Decarli A, Amadori D, Avellini C, Cipriani F, Cocco P, Giacosa A, Lorenzini L, Marubini E, Puntoni R, Saragoni A, Fraumeni JF Jr, Blot WJ: A case-control study of gastric cancer and diet in Italy. III. Risk patterns by histologic type. Int J Cancer 1991, 48:369-374.

13. Chen $H$, Ward MH, Graubard BI, Heineman EF, Markin RM, Potischman NA, Russell RM, Weisenburger DD, Tucker KL: Dietary patterns and adenocarcinoma of the esophagus and distal stomach. Am J Clin Nutr 2002, 75:137-144. 
14. Cornée J, Pobel D, Riboli E, Guyader M, Hémon B: A case-control study of gastric cancer and nutritional factors in Marseille, France. Eur J Epidemiol 1995, 11:55-65.

15. De Stefani $E$, Correa $P$, Boffetta $P$, Deneo-Pellegrini $H$, Ronco $A L$, Mendilaharsu M: Dietary patterns and risk of gastric cancer: a casecontrol study in Uruguay. Gastric Cancer 2004, 7:211-220.

16. Fernandez E, Chatenoud L, La Vecchia C, Negri E, Franceschi S: Fish consumption and cancer risk. Am J Clin Nutr 1999, 70:85-90.

17. Hamada GS, Kowalski LP, Nishimoto IN, Rodriques JJ, Iriya K, Sasazuki S, Hanaoka T, Tsugane S, São Paulo-Japan Cancer Project Gastric Cancer Study Group: Risk factors for stomach cancer in Brazil (II): a case-control study among Japanese Brazilians in São Paulo. Jpn J Clin Oncol 2002, 32:284-290.

18. Hoshiyama $Y$, Sasaba T: A case-control study of single and multiple stomach cancers in Saitama Prefecture, Japan. Jpn J Cancer Res 1992, 83:937-943.

19. Hu J, La Vecchia C, DesMeules M, Negri E, Mery L, Canadian Cancer Registries Epidemiology Research Group: Meat and fish consumption and cancer in Canada. Nutr Cancer 2008, 60:313-324.

20. Muñoz N, Plummer M, Vivas J, Moreno V, De Sanjosé S, Lopez G, Oliver W: A case-control study of gastric cancer in Venezuela. Int J Cancer 2001, 93:417-423.

21. Phukan RK, Narain K, Zomawia E, Hazarika NC, Mahanta J: Dietary habits and stomach cancer in Mizoram, India. J Gastroenterol 2006, 41:418-424.

22. Pourfarzi F, Whelan A, Kaldor J, Malekzadeh R: The role of diet and other environmental factors in the causation of gastric cancer in Iran-a population based study. Int J Cancer 2009, 125:1953-1960.

23. Rao DN, Ganesh B, Dinshaw KA, Mohandas KM: A case-control study of stomach cancer in Mumbai, India. Int J Cancer 2002, 99:727-731.

24. Ito LS, Inoue M, Tajima K, Yamamura Y, Kodera Y, Hirose K, Takezaki T, Hamajima N, Kuroishi T, Tominaga S: Dietary factors and the risk of gastric cancer among Japanese women: a comparison between the differentiated and non-differentiated subtypes. Ann Epidemiol 2003, 13:24-31.

25. Takezaki T, Gao CM, Wu JZ, Ding JH, Liu YT, Zhang Y, Li SP, Su P, Liu TK, Tajima K: Dietary protective and risk factors for esophageal and stomach cancers in a low-epidemic area for stomach cancer in Jiangsu Province, China: comparison with those in a high-epidemic area. Jpn J Cancer Res 2001, 92:1157-1165.

26. Ward MH, López-Carrillo L: Dietary factors and the risk of gastric cancer in Mexico City. Am J Epidemiol 1999, 149:925-932.

27. Larsson SC, Bergkvist L, Wolk A: Processed meat consumption, dietary nitrosamines and stomach cancer risk in a cohort of Swedish women. Int J Cancer 2006, 119:915-919.

28. Ngoan LT, Mizoue T, Fujino Y, Tokui N, Yoshimura T: Dietary factors and stomach cancer mortality. Br J Cancer 2002, 87:37-42.

29. Key TJ, Appleby PN, Spencer EA, Travis RC, Allen NE, Thorogood M, Mann Jl: Cancer incidence in British vegetarians. Br J Cancer 2009, 101:192-197.

30. DerSimonian R, Laird N: Meta-analysis in clinical trials. Control Clin Trials 1986, 7:177-188

31. Higgins JP, Thompson SG, Deeks JJ, Altman DG: Measuring inconsistency in meta-analyses. BMJ 2003, 327:557-560.

32. Hedges LV, Pigott TD: The power of statistical tests in meta-analysis. Psychol Method 2001, 6:203-217.

33. Thornton A, Lee P: Publication bias in meta-analysis: its causes and consequences. J Clin Epidemiol 2000, 53:207-216.

34. Egger M, Davey Smith G, Schneider M, Minder C: Bias in meta-analysis detected by a simple, graphical test. BMJ 1997, 315:629-634.

35. Campbell PT, Sloan M, Kreiger N: Dietary patterns and risk of incident gastric adenocarcinoma. Am J Epidemiol 2008, 167:295-304.

36. Nomura AM, Hankin JH, Kolonel LN, Wilkens LR, Goodman MT, Stemmermann GN: Case-control study of diet and other risk factors for gastric cancer in Hawaii (United States). Cancer Causes Control 2003, 14:547-558.

37. Kim MK, Sasaki S, Sasazuki S, Tsugane S, Japan Public Health Center-based Prospective Study Group: Prospective study of three major dietary patterns and risk of gastric cancer in Japan. Int J Cancer 2004, 110:435-342.

38. Geelen A, Schouten JM, Kamphuis C, Stam BE, Burema J, Renkema JM, Bakker EJ, van't Veer P, Kampman E: Fish consumption, n-3 fatty acids, and colorectal cancer: a meta-analysis of prospective cohort studies. Am J Epidemiol 2007, 166:1116-1125.

39. Lunet N, Valbuena C, Vieira AL, Lopes C, Lopes C, David L, Carneiro F, Barros $\mathrm{H}$ : Fruit and vegetable consumption and gastric cancer by location and histological type: case-control and meta-analysis. Eur $J$ Cancer Prev 2007, 16:312-327.

40. Liu CY, Hsu YH, Wu MT, Pan PC, Ho CK, Su L, Xu X, Li Y, Christiani DC, Kaohsiung Leukemia Research Group: Cured meat, vegetables, and beancurd foods in relation to childhood acute leukemia risk: a population based case-control study. BMC Cancer 2009, 9:15.

41. Engeset D, Dyachenko A, Ciampi A, Lund E: Dietary patterns and risk of cancer of various sites in the Norwegian European Prospective Investigation into Cancer and Nutrition cohort: the Norwegian Women and Cancer study. Eur J Cancer Prev 2009, 18:69-75.

42. Gonzalez CA, Riboli E: Diet and cancer prevention: where we are, where we are going. Nutr Cancer 2006, 56:225-231.

43. Kim J, Lim SY, Shin A, Sung MK, Ro J, Kang HS, Lee KS, Kim SW, Lee ES: Fatty fish and fish omega-3 fatty acid intakes decrease the breast cancer risk: a case-control study. BMC Cancer 2009, 9:216.

44. Pot GK, Majsak-Newman G, Geelen A, Harvey LJ, Nagengast FM, Witteman BJ, van de Meeberg PC, Timmer R, Tan A, Wahab PJ, Hart AR, Williams MP, Przybylska-Phillips K, Dainty JR, Schaafsma G, Kampman E, Lund EK, FISHGASTRO Study Group: Fish consumption and markers of colorectal cancer risk: a multicenter randomized controlled trial. Am J Clin Nutr 2009, 90:354-361.

45. Tsugane S: Salt, salted food intake, and risk of gastric cancer: epidemiologic evidence. Cancer Sci 2005, 96:1-6.

46. Kono S, Hirohata T: Nutrition and stomach cancer. Cancer Causes Control 1996, 7:41-55.

47. World Cancer Research Fund, American Institute for Cancer Research: Food, Nutrition and the Prevention of Cancer: a Global Perspective. Washington: American Institute for Cancer Research; 1997.

48. Ward MH, Lopez-Carrillo L: Dietary factors and the risk of gastric cancer in Mexico City. Am J Epidemiol 1999, 149:925-932.

49. Tsugane S, Sasazuki S, Kobayashi M, Sasaki S: Salt and salted food intake and subsequent risk of gastric cancer among middle-aged Japanese men and women. Br J Cancer 2004, 90:128-134.

50. Kim HJ, Chang WK, Kim MK, Lee SS, Choi BY: Dietary factors and gastric cancer in Korea: a case-control study. Int J Cancer 2002, 97:531-535.

51. Larsson SC, Orsini N, Wolk A: Processed meat consumption and stomach cancer risk: a meta-analysis. J Natl Cancer Inst 2006, 98:1078-1087.

52. Jakszyn P, Gonzalez CA: Nitrosamine and related food intakeand gastric and oesophageal cancer risk: a systematicreview of the epidemiological evidence. World J Gastroen-terol 2006, 12:4296-4303.

53. World Cancer Research Fund/American Institute for Cancer Research: Food, nutrition, physical activity, and the prevention of cancer: a global perspective. Washington, DC: American Institute for Cancer Research; 2007.

54. Mirvish SS: Role of N-nitroso compounds (NOC) andN-nitrosation in etiology of gastric, esophageal, naso-pharyngeal and bladder cancer and contribution to cancerof known exposures to NOC. Cancer Lett 1995, 93:17-48.

55. Dich J, Jarvinen R, Knekt P, Penttila PL: Dietary intakes of nitrate, nitrite and NDMA in the Finnish Mobile Clinic Health Examination Survey. Food Addit Contam 1996, 13:541-552.

56. Knekt $\mathrm{P}$, Jarvinen $\mathrm{R}$, Dich J, Hakulinen T: Risk of colorectal and other gastro-intestinal cancers after exposure to nitrate, nitrite and $\mathrm{N}$-nitroso compounds: a follow-up study. Int J Cancer 1999, 80:852-856.

57. Bingham SA, Pignatelli B, Pollock JR, Ellul A, Malaveille C, Gross G, Runswick S, Cummings JH, O'Neill IK: Does increased endogenous formation of $\mathrm{N}$-nitroso compounds in the human colon explain the association between red meat and colon cancer? Carcinogenesis 1996, 17:515-523.

58. Skog Kl, Johansson MA, Jagerstad Ml: Carcinogenic heterocyclic amines in model systems and cooked foods: a review on formation, occurrence and intake. Food Chem Toxicol 1998, 36:879-896.

59. Chen W, Weisburger JH, Fiala ES, Spratt TE, Carmella SG, Chen D, Hecht SS: Gastric carcinogenesis: 2-chloro-4-methylthiobutanoic acid, a novel mutagen in salted, pickled Sanma hiraki fish, or similarly treated methionine. Chem Res Toxicol 1996, 9:58-66. 
60. Lauren P: The two histological main types of gastric carcinoma: diffuse and so-called intestinal-type carcinoma. An attempt at a histo-clinical classification. Acta Pathol Microbiol Scand 1965, 64:31-49.

61. Palli D, Bianchi S, Cipriani F, Duca P, Amorosi A, Avellini C, Russo A, Saragoni A, Todde P, Valdes E, Vindigni C, Blot WJ, Fraumeni JF, Buiattil Jr: Reproducibility of histologic classification of gastric cancer. $\mathrm{Br} J$ Cancer 1991, 63:765-768.

62. Correa P, Shiao YH: Phenotypic and genotypic events in gastric carcinogenesis. Cancer Res 1994, 54:1941S-1943S.

63. Harrison LE, Zhang ZF, Karpeh MS, Sun M, Kurtz RC: The role of dietary factors in the intestinal and diffuse histologic subtypes of gastric adenocarcinoma: a case-control study in the U.S. Cancer 1997, 80:1021-1028

64. Koh TJ, Wang TC: Tumors of the stomach. In Sleisenger and Fordtran's gastrointestinal and liver disease: pathophysiology, diagnosis, and management. Edited by: Feldman M. Philadelphia, Saunders; 2001:829-851.

65. Larsson SC, Giovannucci E, Wolk A: Folate intake and stomach cancer incidence in a prospective cohort of Swedish women. Cancer Epidemiol Biomarkers Prev 2006, 15:1409-1412.

66. Larsson SC, Bergkvist L, Wolk A: Processed meat consumption, dietary nitrosamines and stomach cancer risk in a cohort of Swedish women. Int J Cancer 2006, 119:915-919.

67. Hilakivi-Clarke L, Olivo SE, Shajahan A, Khan G, Zhu Y, Zwart A, Cho E, Clarke R: Mechanisms mediating the effects of prepubertal $(n-3)$ polyunsaturated fatty acid diet on breast cancer risk in rats. J Nutr 2005, 135:2946S-2952S.

68. Ford $\mathrm{JH}$ : Saturated fatty acid metabolism is key link between cell division, cancer, and senescence in cellular and whole organism aging. Age (Dordr) 2010, 32:231-237.

69. James MJ, Proudman SM, Cleland LG: Dietary n-3 fats as adjunctive therapy in a prototypic inflammatory disease: issues and obstacles for use in rheumatoid arthritis. Prostaglandins Leukot Essent Fatty Acids 2003, 68:399-405.

70. Cerchietti LC, Navigante AH, Castro MA: Effects of eicosapentaenoic and docosahexaenoic $n-3$ fatty acids from fish oil and preferential Cox-2 inhibition on systemic syndromes in patients with advanced lung cancer. Nutr Cancer 2007, 59:14-20.

71. Stoll BA: N-3 fatty acids and lipid peroxidation in breast cancer inhibition. Br J Nutr 2002, 87:193-198.

72. Roynette CE, Calder PC, Dupertuis YM, Pichard C: $n-3$ polyunsaturated fatty acids and colon cancer prevention. Clin Nutr 2004, 23:139-151.

73. Chapkin RS, Davidson LA, Ly L, Weeks BR, Lupton JR, McMurray DN: Immunomodulatory effects of ( $n-3)$ fatty acids: putative link to inflammation and colon cancer. J Nutr 2007, 137(Suppl 1):200S-204S.

74. Dai Q, Shu XO, Jin F, Gao YT, Ruan ZX, Zheng W: Consumption of animal foods, cooking methods, and risk of breast cancer. Cancer Epidemiol Biomarkers Prev 2002, 11:801-818.

75. van Vliet T, Katan MB: Lower ratio of $n-3$ to $n-6$ fatty acids in cultured than in wild fish. Am J Clin Nutr 1990, 51:1-2.

76. Gago-Dominguez M, Yuan JM, Sun CL, Lee HP, Yu MC: Opposing effects of dietary n-3 and n- 6 fatty acids on mammary carcinogenesis: The Singapore Chinese Health Study. Br J Cancer 2003, 89:1686-1692.

77. Hall MN, Campos H, Li H, Sesso HD, Stampfer MJ, Willett WC, Ma J: Blood levels of long-chain polyunsaturated fatty acids, aspirin, and the risk of colorectal cancer. In Cancer Epidemiol Biomarkers Prev. Volume 16. New York, Oxford: Oxford University Press; 2007:314-321.

78. Willett W: Food-frequency methods. In Nutritional epidemiology. 2 edition. Edited by: Willett W. New York, Oxford: Oxford University Press; 1998:74-100

79. Mayer-Davis EJ, Vitolins MZ, Carmichael SL, Hemphill S, Tsaroucha G, Rushing J, Levin S: Validity and reproducibility of a food frequency interview in a Multi-Cultural Epidemiology Study. Ann Epidemiol 1999, 9:314-324

\section{Pre-publication history}

The pre-publication history for this paper can be accessed here: http://www.biomedcentral.com/1471-2407/11/26/prepub

doi:10.1186/1471-2407-11-26

Cite this article as: Wu et al.: Fish consumption and the risk of gastric cancer: systematic review and meta-analysis. BMC Cancer 2011 11:26.

\section{Submit your next manuscript to BioMed Central and take full advantage of:}

- Convenient online submission

- Thorough peer review

- No space constraints or color figure charges

- Immediate publication on acceptance

- Inclusion in PubMed, CAS, Scopus and Google Scholar

- Research which is freely available for redistribution

Submit your manuscript at www.biomedcentral.com/submit 